\title{
Aktuální stav, právní předpoklady a východiska soukromoprávního vymáhání škody způsobené porušením soutěžního práva $\mathbf{v}$ ČR*
}

\section{Current Conditions, Legal Premises and Background of Private Enforcement of Damage Claims from Competition Law Infringements in the Czech Republic}

\author{
Tomáš Kubeša ${ }^{* *}$
}

\begin{abstract}
Abstrakt
$V$ dubnu 2014 byla prïjata nová smèrnice o soukromoprávnim vymáháni škody z.porušeni soutěžního práva. Tato smèrnice má za cíl zlepšit podminky pro soukromoprávni žaloby v této oblasti. Presto, že pred českými soudy probíhá rada řżeni v těchto vécech, stále nejsou k dispozici žádná pravomocná rozhodnutí. Tento článek se pokouši porovnat nové nástroje, zavádèné smèrnici s již existujicími nástroji, použitelnými žalobci pro vymáháni škody. Článek se také pokouši prèdpovèdèt, zdali nová smèrnice bude dostatečnou pobidkou, vedouci ke zvýseni počtu a úspěšnosti žalob na nábradu škody v soutě̃unich vécech.
\end{abstract}

Klíčová slova

Vymáháni škody; soutéẓni právo; žalobni legitimace; vyčisleni nároku; duikazni situace; próstup do správníbo spisu.

\begin{abstract}
In April 2014, a new directive on private enforcement of damage claims from competition law infringements has been adopted. The directive attempts to improve the conditions for private actions in the field. Although there is a relatively rich case law in the public enforcement of competition law and damage claim cases pending in Czech courts, there are no final decisions yet. The article attempts to compare the new tools offered by the directive with existing tools available to plaintiffs for use in enforcement of their damage claims. The article also attempts to predict whether the new directive provides sufficient incentives to increase the number and success rate of damage claims from competition law infringements.
\end{abstract}

Keywords

Damage Litigation; Competition Law; Right of Action; Calculation of Damages; Standard of Proof; Access to File.

\footnotetext{
* Článek vznikl v rámci projektu specifického výzkumu č. MUNI/A/1321/2014.

** Mgr. Tomáš Kubeša, doktorand, Katedra občanského práva, Právnická fakulta Masarykovy univerzity, Brno / Ph.D. student, Department of Civil Law, Faculty of Law, Masaryk University, Brno, Czech Republic / E-mail: tomas.kubesa@mail.muni.cz
} 


\section{1 Úvod $^{1}$}

V dubnu 2014 došlo k přijetí směrnice ke zlepšení podmínek pro vymáhání náhrady škody způsobené porušením hospodářské soutěže ${ }^{2}$. Tato směrnice obsahuje nástroje k implementaci do národních právních řádů do konce roku 2015. Nastala tak př́ležitost k funkčnímu nastavení tohoto systému v ČR. V současné době totiž platí, že škoda, vzniklá jako důsledek porušení norem soutěžního práva, je vymáhána v minimální míre. V obecnou známost vešly pouze běžící prrípady $O 2$ vs. Volny a ČD vs. RegioJet / LeoExpre$s s^{5}$. Oba tyto případy běží již řadu let, stále však nedospěly k pravomocnému rozhodnutî ve věci. Platí přitom, že řada dalších úspěšně uzavřených soutěžních prrípadư ${ }^{6}$ nebyla následována žalobami na náhradu způsobené škody. Česká republika se tak řadí po bok těch evropských států, kde nelze soukromoprávní větev vymáhání soutěžního práva7 označit za funkční. Oproti tomu v řadě dalších evropských států se daří vymáhat škodu z porušení soutěžního práva poměrně úspěšně a nové př́pady jsou zaznamenávány pravidelně.

1 Odevzdáno do recenzního řízení ke dni 12. 10. 2015, tedy před vstupem návrhu transpozičního zákona ze strany ÚOHS do legislativního procesu.

2 Směrnice Evropského parlamentu a Rady 2014/104/EU ze dne 26. listopadu 2014 o určitých pravidlech upravujících žaloby o náhradu škody podle vnitrostátního práva $\mathrm{v}$ př́ípadě porušení právních předpisů členských států a Evropské unie o hospodářské soutěži, dále též „směrnice“.

3 O soudním sporu informováno nap̌̌. v článku Volný žaluje Telefónileu O2 o 4 miliardy. Za príliš levný internet. iDnes.cz. 30. 3. 2011. Cit. dne 20. 7. 2015. Dostupný na http://ekonomika.idnes.cz/spravni-rizeni-s-telefonikou-o2-d35-/ekonomika.aspx?c=A110330_090802_ekonomika_vem

4 O soudním sporu informováno nap̌r. v článku České dráhy prý jezdily za podnákladové ceny. RegioJet žádá odškodnění. Deník.cz. 1. 6. 2015. Cit. dne 20. 7. 2015. Dostupný na http://www.denik.cz/ekonomika/regiojet-zaluje-ceske-drahy-o-717-milionu-korun-20150601.html

5 O soudním sporu informováno nap̌r. v článku LeoExpress zažaloval ČD za predátorské ceny na trati do Ostravy. iDnes.cz. 2. 7. 2014. Cit. dne 20. 7. 2015. Dostupný na http://ekonomika.idnes. cz/leo-express-zazaloval-cd-za-predatorske-ceny-na-trati-do-ostravy-pxx-/eko-doprava. aspx?c=A140702_212704_eko-doprava_aha

6 Tyto lze dohledat ve sbírce rozhodnutí ÚOHS na https://www.uohs.cz/cs/hospodarska-soutez/sbirky-rozhodnuti.html. Zmínit lze např́ílad př́ípady Odpady sp. zn. S346/2010/KD, Hasiči sp. zn. S600/2013/ KD či Škoda Auto sp. zn. S360/2014.

7 NERUDA, Robert. Soukromé či veřejné prosazování soutěžního práva? ANTITRUST: Revue soutě̌žního práva. Praha, 2011, č. 4, s. 154-160. ISSN 1804-1183.

8 Situaci v Německu přehledně rozebírají BUNTSCHECK, M., STICHWEH, H. Germany: Private Antitrust Litigation. Global Competition Review. 2015. Cit. dne 20. 7. 2015. Dostupné na http://globalcompetitionreview.com/reviews/62/sections/210/chapters/2490/germany-private-antitrust-litigation/

Shrnutí situace v Nizozemsku, Velké Británii a Německu nabízí KUIJPERS, M., TUINENGA, S. a kol. Actions for Damages in the Netherlands, the United Kingdom, and Germany. Journal od European Competition Law «Practice. 2015. Cit. dne 14. 6. 2016. Dostupné na https://www.stibbe.com/ /media/03\%20 news/publications/amsterdam/stefan $\% 20$ tuinenga/journal $\% 20$ of $\% 20$ european $\% 20$ competitionlaw $\% 20 \% 20$ practice-2015-jeclap-lpu125.pdf 
V tomto př́spěvku se zaměřím na nástroje, které české právo zná k vymáhání škody z porušení soutěžního práva $v$ novém občanském zákoníku. Dále se pokusím identifikovat slabiny těchto nástrojů pro použití na danou materii a zhodnotím, z jaké situace budou vycházet snahy o transpozici směrnice.

\section{Porušení soutěžních norem a vznik škody}

Před samotným výkladem o náhradě škody jako takové je nezbytné přiblížit specifika, která soutěžní právo ve zkoumané problematice přináší. Pro potřeby tohoto př́spěvku bude dostačující stručný vhled s tím, že zájemcům o problematiku je k dispozici dostatek jiných, specializovaných zdrojů?

Porušením hospodářské soutěže rozumíme nejčastěji uzavření zakázané horizontální dohody $^{10}$, vertikální dohody ${ }^{11}$, zneužití dominantního postavení ${ }^{12}$ či porušení zákona v oblasti fúzí13 ${ }^{13}$ Tyto delikty jsou považovány za velmi závažné, nebot' omezují vliv volné soutěže na trhu a tím narušují samotnou podstatu tržní ekonomiky. Obecně vedou k nahrazení autonomního chování a rozhodování soutěžitele chováním jiným, odvozeným od dohody či vưle jiného subjektu.

V obecné rovině lze konstatovat, že vlivem porušení soutěžních norem dochází ke zhoršení kvality soutěžního prostředí, k omezení konkurenčního tlaku a tím ke zpomalení výzkumu a vývoje, omezení inovací, poklesu konkurenceschopnosti, růstu neefektivity a zvýšení cen ${ }^{14}$. Obecné odhady hovoři o zvýšení cen v širokém rozpětí od jednotek až do desítek procent, a to $\mathrm{v}$ závislosti na specifikách daného trhu ${ }^{15}$. Toto zvýšení cen je obvykle částečně absorbováno v distribučním řetězci, částečně pak přeneseno na spotřebitele ${ }^{16}$. Stejně tak další dopady protisoutěžního jednání jsou v konečném důsledku

9 Př́kladmo PETR, Michal. Zakázané dohody a zneužití dominantního postavení v ČR. 1. vyd., Praha: C H Beck, 2010. RAUS, David, NERUDA, Robert. Zákon o ochraně hospodárské soutěže: Komentár a souvisici české i komunitárni prèdpisy. 2. aktual. a přeprac. vyd., Praha: Linde Praha, 2006. PETR, Michal. Modernizace komunitárníbo soutě̃̌ního práva. 1. vyd., Praha: C. H. Beck, 2008.

10 \ 3 odst. 1 a) zákon č. 143/2001 Sb., o ochraně hospodářské soutěže a o změně některých zákonů (zákon o ochraně hospodářské soutěže), dále též „ZOHS“.

11 \5 odst. 2 ZOHS.

12 \10 a násl. ZOHS.

13 \ 12 a násl. ZOHS.

14 KOMNINOS, Assimakis. Quantifying antitrust damages. Lucemburk: Úřad pro publikace Evropské unie, 2009, s. 15. Cit. dne 20. 7. 2015. Dostupný na: http://ec.europa.eu/competition/antitrust/actionsdamages/quantification_study.pdf

15 KOMNINOS, Assimakis. Quantifying antitrust damages. Lucemburk: Úřad pro publikace Evropské unie, 2009, s. 88 a násl. Cit. dne 20. 7. 2015. Dostupný na: http:/ / ec.europa.eu/competition/antitrust/actionsdamages/quantification_study.pdf

16 VALOUŠKOVÁ, Zuzana. Nad návrhem směrnice na podporu soukromoprávního vymáhání antitrustových škod. ANTITRUST: Revue soutěžního práva. Praha, 2013, č. 3, s. 95. ISSN 1804-1183. 
přeneseny na spotřebitele. Vyčíslení necenových dopadů protisoutěžních deliktů je pak třeba posuzovat se zohledněním specifik daného případu a je enormně náročné.

Dále platí, že porušení soutěžních norem jsou často umně skrývána jejich pachateli. Orgány, zaměřené na jejich odhalování, vyšetřování a sankcionování17 vyvinuly specializované nástroje, které mají jejich činnost usnadnit a zvýšit jejich efektivitu ${ }^{18}$. Tyto orgány mají, v zájmu existenčního zachování správněprávní větve vymáhání soutěžního práva, nejvyšší zájem na ochraně těchto nástrojů. Zároveň platí, že v řízeních před těmito orgány je operováno s řadou specifických pojmů, které nenachází v občanském právu přesný odraz. Dále lze konstatovat, že poškozený má relativně nízké šance na samostatné odhalení protisoutěžního jednání (zejména kartelu) v dostatečné kvalitě19 ${ }^{19}$, nezbývá tak než se spolehnout na výsledky vyšetřování protisoutěžního jednání ve správněprávní větvi.

Vymáhání škody způsobené porušením soutěžního práva je nezbytné vnímat v komplexu s výše uvedenými skutečnostmi.

\section{Současné nástroje pro vymáhání škody}

Nejsilnějším současným nástrojem pro vymáhání škody z porušení soutěžního práva je žaloba na náhradu škody dle \2910 NOZ ${ }^{20}$. Dikce tohoto zákonného ustanovení zdá se vcelku jednoznačná, vzhledem ke specifikům předchozí kapitoly se však objevují značné problémy, které je nezbytné překlenout.

Zákon uvažuje v S 2910 NOZ s několika předpoklady. Je jím existence jasně identifikovatelného škůdce, který způsobil škodu. Dále uvažuje, že takový škůdce nahradí, co zprisobil, existuje tedy možnost určit výši škody a tím i náhrady. NOZ umožňuje získat kromě náhrady škody jako takové i ušlý zisk ${ }^{21}$. Dále předpokládá, že bude nahrazeno poškozenému, tedy takovému subjektu, jehož majetková sféra se vinou škůdce zmenšila (damnum emergens) či se nezvětšila předpokládaným způsobem (lucrum cesans).

Vyžaduje tedy jasný závěr o aktivní i pasivní žalobní legitimaci, výši a důvodu nároku.

$17 \mathrm{~V}$ českém právním prostředí jsou relevantní Úřad pro ochranu hospodářské soutěže a Evropská komise.

18 Př́ikladmo Leniency program (dle Oznámení Úřadu pro ochranu hospodářské soutěže ze dne 4. listopadu 2013 o aplikaci \22ba odst. 1 zákona o ochraně hospodářské soutěže dostupného na https://www. uohs.cz/cs/legislativa/hospodarska-soutez.html) a Procedura narovnání dle Oznámení ÚOHS o proceduře směřující k urychlení průběhu správního řízení využitím institutu žádosti o snížení pokuty dle $\int 22$ ba odst. 2 zákona o ochraně hospodářské soutěže dostupného tamtéž).

19 NERUDA, Robert. Soukromé či veřejné prosazování soutěžního práva? ANTITRUST Revue soutěžního práva, Praha, 2011, č. 4, ISSN 1804-1183, s. 154-160.

20 \2910 zákona č. 89/2012 Sb., občanský zákoník, dále též NOZ. Lze uvažovat i o bezdůvodném obohacení.

21 \2952 NOZ. 
Velmi silné je ustanovení \2955, dle kterého může k určení výše náhrady přikročit soud, které do značné míry odpovídá procesnímu ustanovení \136 OSŘ²2. Zde platí, že soud není oprávněn určit výši náhrady svévolně, naopak musí předestř́it důkazně kvalitně podloženou úvahu, na které svưj úsudek založí. Dále platí, že o režim \136 OSŘ se nelze oprrít při určení vzniku škody jako takové, jejího důvodu, případně identitě škůdce, je použitelný pouze pro stanovení její výše. I v této podobě však představuje silný nástroj, usnadňující důkazní situaci žalobce.

Pro žalobu na náhradu škody z porušení soutěžního práva lze užít všech nástrojů k zajištění důkazních prostředků, jak je zná OSŘ.

\section{Slabiny užívaných nástrojů}

Z výše uvedených skutečností lze dovodit, že vymáhání škody z porušení soutěžního práva čelí značným překážkám. Tyto překážky přitom vyplývají prímo ze samotných základů pojetí soutěžního a občanského práva, jejich překonání je tak značně komplikované. $\mathrm{V}$ dalším textu budou tyto překážky představeny.

\section{Pasivní žalobní legitimace}

Jak již bylo uvedeno, naděje na odhalení protisoutěžního jednání samotným poškozeným je nízká. Základem protisoutěžních deliktů je přitom nejčastěji komunikace mezi delikventy (směřující k zakázané dohodě či obsahující zneužívací prvky) ryze obchodní povahy, které není dostupná navenek. Protisoutěžní delikty jsou jejich pachateli v dnešní době již intenzivně utajovány. Na samotných vnějších projevech soutěžního deliktu (cena nad úrovní, dosažitelnou volnou soutěžî) přitom není možné závěr o deliktu založit ${ }^{23}$. Nezbývá tak, než se spolehnout na výsledky správních řízení vedených soutěžním úřadem. Zde přitom narážíme na první komplikaci. Soutěžní regulace považuje za adresáta svých norem soutéžitele ${ }^{24}$, tedy velmi široce pojatou entitu, která nemusí nutně mít právní subjektivitu. Za účastníka řízení přitom bere subjekt, který za dané jednání odpovídá z pohledu soutěžního práva, tedy v autonomním pojetí. K určení takového subjektu je užíváno hned několik teorií, mezi nimi teorie jediné hospodárské jednotky ${ }^{25}$. Takový subjekt přitom nemusí být přímo stranou protisoutěžní dohody ani vstupovat do právních vztahů se smluvními partnery, potenciálními poškozenými. Nemusí dokonce ani disponovat rozsáhlým majetkem, ze kterého by bylo možné poškozené uspokojit. Je dostačující, pokud vykonává rozhodující vliv na chování dané společnosti či pokud je konečným

22 \136 zákona č. 99/1963 Sb., občanský soudní řád, dále též OŠ̌.

23 Nebot’ jednání, reprobované v $₫ 3$ odst. 1 má charakter dohody, jejím definičním znakem je tak shoda vưle jejích stran. Bez dostatečného prokázání tohoto znaku nelze o protisoutěžním deliktu uvažovat.

$24 \rrbracket 2$ odst. 1 ZOHS.

25 WENNER, Frédérique, VAN BARLINGEN, Bertus. European Court of Justice confirms Commission's approach on parental liability. Competition Policy Newsletter. Brusel, 2010, č. 1. Cit. dne 20. 7. 2015. Dostupný na http://ec.europa.eu/competition/publications/cpn/2010_1_9.pdf 
př́jemcem zisků z porušení soutěžních norem. Není výjimkou, že takovým účastníkem řízení je zahraniční subjekt ${ }^{26}$. Oproti tomu pasivně legitimovaný ve smyslu občanskoprávním bude ten, u koho budou splněny zákonné požadavky na delikt, škodu, kauzální nexus a zavinění v občanskoprávním pojetí. Lze tedy říci, že je na poškozeném, aby posoudil, určil a dokázal, kdo je pasivně legitimovaný subjektem, kterého bude následně žalovat se svým nárokem, na správněprávní větev vymáhání soutěžního práva se nelze spolehnout. Volba subjektu, kterému nelze odpovědnost za delikt prriřknout, popřípadě jeho vztah $\mathrm{k}$ odpovědnosti je slabý ovšem může vést $\mathrm{k}$ nedostatku v kauzálním nexu a potenciálně procesnímu neúspěchu žalobce.

\section{Aktivní žalobní legitimace}

Pokud jde o určení aktivní žalobní legitimace, situace je obdobně komplikovaná. Přričina této komplikace je v častém způsobu rozdělení vzniklé škody v distribučním řetězci. Dle tohoto modelu je cena, zvýšená vlivem protisoutěžního jednání (a tedy zahrnující i škodu) placena subjektem na prvním stupni distribučního řetězce, tomuto subjektu tedy vzniká škoda. Část tohoto zvýšení ceny je však následně přenesena na další stupeň v distribučním řetězci. I subjekty na dalším stupni distribučního řetězce tak utrpí škodu, byt' sníženou, stejně tak i tyto subjekty zvýší cenu a přesouvají tak škodu dále, až ke konečnému spotřebiteli. Žádný z těchto subjektů již nemá přímý vztah s původním škůdcem. Majetek žádného z nich nezmenší o celou výši škody a s výjimkou prvního odběratele $\mathrm{v}$ distribučním řetězci je nepojí se škůdcem vztah zavinění, není ani dán kauzální nexus. Konstruovat odpovědnostní vztahy v rámci distribučního řetězce pak nebude vhodné, nebot' nikdo jiný než škůdce jakožto pachatel protisoutěžního deliktu nezpůsobil delikt, odpovědnost zde tedy nevzniká.

\section{Vyčíslení nároku}

Již naznačeným problémem je taktéž určení výše škody a tedy i žalovaného nároku. V této situaci se opět nelze spolehnout na rozhodnutí soutěžního orgánu, nebot' ten ve své činnosti nepřistupuje k vyčíslování škody. Ostatně zákon soutěžnímu orgánu toto ani neukládá, dle současné právní úpravy od něj tedy nelze ani takový postup očekávat. Obzvláště u vertikálních soutěžních deliktů může dojít k užití ekonomických analýz v rámci konstrukce teorie újmy ${ }^{27}$, nicméně taková analýza se spokojí s konstatováním, zdali škoda vznikla či nikoliv, určení její přesné výše již ve správním řízení není účelné.

$26 \mathrm{~V}$ českém právním prostředí je to poměrně běžná praxe, viz příkladmo rozhodnutí ÚOHS ve věcech Výrobci CRT, sp. zn. S013/09/KD, PISU, sp. zn. S222/06/KD, Pracíprášky, sp. zn. S169/08/KD a řada dalších, které lze taktéž dohledat ve sbírce rozhodnutí ÚOHS na https:/ /www.uohs.cz/cs/hospodarska-soutez/sbirky-rozhodnuti.html

27 ZENGER, Hans, WALKER, Mike. Theories of harm in European competition law: A progress report. Ten years of effects-based approach in EU Competition law. 2012. Cit. dne 20. 7. 2015. Dostupný na http://ssrn.com/ abstract $=2009296$ 
Vyčíslení výše škody v soutěžním právu naráží na několik zásadních komplikací. Je nutné si uvědomit, že soutěžní delikty nevedou jen ke zvýšení cen, ale i ke zmiňovaným dalším důsledkům, jako jsou omezení inovací a konkurenceschopnosti či růstu neefektivity. Tyto necenové dopady je velmi náročné vyčíslit v penězích či dokonce snad přistoupit k uvedení do původního stavu či jejich odstranění.

Vyčíslení cenových dopadů však není jednodušší. Pro určení výše škody je nezbytné stanovit hypotetickou tržní cenu, která by na trhu byla dosahována nebýt soutěžního deliktu. Následně je nutné porovnat skutečnou cenu s touto hypotetickou cenou s tím, že právě jejich rozdíl je škodou. Je žrejmé, že takový postup bude velmi důkazně náročný a povede ke snadno napadnutelným výsledkům ${ }^{28}$.

\section{Diokazní situace}

Zcela zásadním problémem je značná důkazní nouze na straně poškozeného v postavení žalobce. Řada protisoutěžních praktik je velmi pečlivě utajována jako celek, poškozený subjekt má jen minimální šanci na odhalení takové praktiky. Při dokazování protisoutěžní praktiky jako deliktu, jsou pak možnosti poškozeného mizivé. Je dobře zdokumentovanou skutečností, že dokonce i soutěžní úrady, vybavené řadou silných pravomocí, považují právě dokazování deliktu za největší komplikaci při ochraně hospodářské soutěže, byt' ve svém specifickém veřejnoprávním pojetí. Poškozený bez těchto pravomocí je pak ve své důkazní situaci dále oslaben. Za připomenutí stojí, že typický horizontální protisoutěžní delikt vyžaduje ke svému prokázání řadu okolností, mezi nimi dohodu soutěžitelů, vzájemných konkurentů. K prokázání takové dohody je nezbytné prokázat vzájemnou komunikaci delikventů se závadným obsahem, přičemž poškozenému chybí nástroje, jak se k takové komunikaci dostat.

\section{Možnosti aktuálních nástrojů}

Výše popsané komplikace představují jen ty nejzřejmější nástrahy, které čekají žalobce při uplatnění jeho nároku na náhradu škody. Zajisté existují i další komplikace, které je třeba pro úspěch žaloby překonat, nicméně ambicí tohoto článku není komplexní přehled všech partikulárních problematických situací. Zajisté lze předpokládat, že případná budoucí rozhodovací praxe nabídne dostatek dalších komplikací ke studiu. Dále se pokusím představit řešení naznačených problémů, majících oporu v současném českém právním řádu, tedy před promítnutím předmětné směrnice.

28 V detailech lze nahlédnout do Praktického průvodce. Určení výše škody v žalobách o náhradu škody při porušení článku 101 nebo 102 Smlouvy o fungování Evropské unie. Průvodní dokument k Sdělení Komise o určení výše škody v žalobách o náhradu škody při porušení článku 101 nebo 102 Smlouvy o fungování Evropské unie. Cit. dne 14. 6. 2016. Dostupný na http://ec.europa.eu/competition/antitrust/actionsdamages/quantification_guide_cs.pdf. Detailní analýza této prríručky svým rozsahem výrazně překonává rozsah tohoto prŕíspěvku. 


\section{K pasivní žalobní legitimaci}

Jádrem této komplikace je nesoulad mezi pojmy soutěěitel a žalovaný či škůdce pro účely vymáhání škody z porušení soutěžních norem. Řešení této komplikace naštěstí není nijak složité. Po žalobci bude vyžadovat, aby jako žalované určil společně a nerozdílně všechny části soutěžitele, disponující právní subjektivitou, které se podle jeho právního názoru mohly na deliktu účastnit, a to včetně jejich podílu na vzniku škody. Pozice soudu při rozhodování tak bude zjednodušena - v př́ípadě, že některý z žalovaných bude nucen hradit více, než odpovídá jeho podílu na vzniku škody, uplatní se regres. Jsem přesvědčen o tom, že u ekonomických jednotek, odpovídajících označení soutěžitel, nebude regres uplatňován v rozhodující míře. Oporu pro toto tvrzení nacházím již v samotném vymezení soutěžitele jako jednotky, sdílející své zisky a jednotné vedení. Taková regresní náhrada $\mathrm{v}$ rámci soutěžitele bude $\mathrm{v}$ řadě případů nadbytečná, nebot' soutěžitel může sám upravit své poměry mezi jednotlivými zúčastněnými subjekty, nebude se tedy obracet na soud a vyhne se litigačním nákladům.

\section{K aktivní Žalobní legitimaci}

V debatách o nové směrnici je častým tématem právě problematika aktivní žalobní legitimace, respektive postavení žalobce, a to ve dvou hlavních oblastech. Oblastí první je problematika tzv. passing on, neboli přenosu škody do distribučního řetězce, oblastí druhou pak navazující problematika vymezení poškozených subjektů.

Při tzv. passing on dochází k promítnutí zvýšení ceny v důsledku protisoutěžního deliktu do cen, účtovaných dalším odběratelům. Přímému odběrateli delikventa tak vzniká pouze škoda, která neodpovídá celému zvýšení ceny, ale pouze zvýšení ceny po odečtení částky, o jakou tento odběratel sám zvýšil cenu svým zákazníkům, tedy škoda nižší. K obdobnému chování se přitom mohou přiklonit i další subjekty v distribučním řetězci. Takové subjekty budou přitom v komplikovaném postavení - s každým dalším stupněm, který je bude $\mathrm{v}$ distribučním řetězci dělit od delikventa, slábne příčinná souvislost mezi škodou a deliktem.

Nelze zapomínat, že žaloby vycházející z jednotlivých článků distribučního řetězce se budou týkat téhož delikventa, deliktu či zboží, případně budou vykazovat i další shodné prvky. $\mathrm{V}$ př́padě, že dojde $\mathrm{k}$ překryvům mezi žalobními nároky, vzniká možnost důvodně podat námitku litispedence či dokonce věci rozhodnuté. Následné vyjasňování vztahu mezi žalobami pak bude představovat značnou výzvu.

Úvahy o přenesení škody umožňují i situaci, kdy je celé zvýšení ceny přeneseno v plném rozsahu na další články distribučního řetězce, popřípadě až na spotřebitele. Přímým a dokonce ani následným odběratelům relevantního produktu pak škoda dle konceptu passing on nevzniká. Zdá se, že tento koncept je přitom nezbytný. Jeho opuštění by vedlo k poněkud absurdním závěrům. Př́mý odběratel delikventa by totiž byl aktivně legitimován k uplatnění nároku na celou škodu (rozumějme celé zvýšení ceny v důsledku 
protisoutěžního deliktu), a to i v situaci, kdy toto zvýšení ceny přenesl na své zákazníky, ke snížení jeho majetku by tak ve skutečnosti nedošlo. Tito by však také byli nuceni nést zvýšené ceny v důsledku protisoutěžního deliktu, škoda by jim tak vznikala taktéž. Stejně jako odběratel na začátku distribučního řetězce by mohli nárokovat celou škodu. V současných distribučních systémech přitom není výjimkou zapojení desítek článků, z nichž každý by, dovedeno do krajnosti, mohl nárokovat celou výši škody.

Řešením není ani vzájemné vypořádání mezi jednotlivými články distribučního řetězce. Žádný ze zapojených subjektů se nedopustil protiprávního jednání, chybí tedy delikt jako základní prvek odpovědnosti za škodu. Náš právní řád přitom obdobu regresu na straně žalobců nezná.

Jako poměrně slibné se však jeví řešení spočívající v pluralitě žalobců, tedy v hromadné žalobě všech prŕpadných poškozených. Toto řešení má však řadu specifických problémů, dostatečně popsaných ve specializované literatuře ${ }^{29}$.

Lze tedy dovodit, že koncept passing on je pro efektivní systém vymáhání škody z protisoutěžních deliktů nezbytný, přináší však řadu komplikací, mezi nimi riziko námitky litispedence a obtížné vyčíslení nároků. Přesto však tento koncept lze užít i ve stávajícím právním rámci pro vymáhání škody, nepřestavuje zásadní novinku, která by vyžadovala změny v právním řádu.

\section{K vyčíslení nároku}

Největší komplikací při úvahách o vymáhání škody z protisoutěžních deliktů se řadě autorů jeví určení její výše, respektive vyčíslení nároku. Důvody jsou naznačeny výše obvykle neexistují jasné důkazy vypovídající o výši škody a je nezbytné se opřít o fundovanou aproximaci, obvykle v podobě ekonomické analýzy. Takto vyčíslený nárok však není dokonale důkazně podepřen, $v$ teorii předcházející směrnici je tak vnímán jako slabý. Posílení důkazní situace žalobce přitom je často vnímáno jako nutná podmínka k úspěšnosti systému vymáhání škody z protisoutěžních deliktů. Tyto úvahy jsou silně zakořeněné a mylné.

Správné vyčíslení výše nároku je nezbytné v př́padech, kdy je aplikován koncept passing on. Zde je nezbytné zajistit, aby celkový součet všech přiznaných náhrad jednotlivým žalobcům nebyl vyšší než celková způsobená škoda. Takový závěr by sám o sobě vypovídal o chybném postupu při vyčíslení škody a byl jasnou známkou pochybení.

Již z právní teorie je dobře známo ${ }^{30}$, že při dokazování se soud pokouší prriblížit skutkovému stavu, avšak naprostou jistotu o něm z důkazních prostředků získat nemůže. Tento teoretický koncept lze nalézt i v občanském zákoníku a občanském soudním řádu, ve kterých je vyjádřen vzájemně blízkým způsobem.

29 WINTEROVÁ, Alena. Hromadné žaloby (procesualistický pohled). Bulletin advokacie, Praha, 2008, č. 10.

30 HOLLÄNDER, Pavel. Filosofie práva, 2. Rozšířené vydání. Praha: Aleš Čeněk, 2012, s. 195. 
Jak občanský zákoník, tak i občanský soudní řád předpokládají, že ve vybraných př́padech nebude možné dokázat přesnou výši vzniklé škody a tím i vyč́slit nárok a podložit jej vyčerpávajícím způsobem důkazy. Pro takové případy ponechávají soudu možnost výši škody určit. Soud prítom nesmí postupovat libovolně, naopak musí svou úvahu o výši škody zdůvodnit. Př́i takové úvaze se tak může oprúít př́kladmo právě o ekonomickou analýzu, provedenou účastníky řízení, či o jiné skutečnosti, tvrzení a důkazy, navržené jak žalovaným, tak i žalobcem.

Ostatně situace, ve kterých není možné důkazně podložit přesnou výši nároku, nejsou v právním řádu nijak vzácné. $V$ občanském právu lze zmínit peněžité náhrady nemajetkové újmy (typicky na dobré pověsti) či nároky z nekalé soutěže. $V$ jiných právních odvětvích je problematika dobře známá $z$ oblasti škod na životním prostředí a určení jim odpovídajících náhrad. Soudy ve všech těchto případech přitom opírají svá rozhodnutí o široké spektrum důkazních prostředků, analýzy užívající hypotetických situací nevyjímaje, klíčovou roli hraje judikatura.

Lze uzavřít s tím, že současný právní rád obsahuje v ustanovení občanského zákoníku a občanského soudního řádu dostatečné nástroje pro určení výše nároku a jsou schopny $\mathrm{s}$ takto určeným nárokem dále operovat.

\section{K diokazní situaci}

Značným problémem, vnímaným poškozenými protisoutěžními delikty, je důkazní nouze. Jak již bylo v tomto článku opakovaně rozebíráno, protisoutěžní delikty jsou mnohdy pečlivě utajované, existuje o nich jen velmi málo důkazů. Pro vymezení delikty, vzniku škody a vyčíslení nároku je přitom nezbytné navrhnout soudu soubor jednoznačných důkazů. Takové důkazy je přitom nutné bud' prrímo předložit, nebo dostatečně popsat tak, aby je mohl obstarat ${ }^{31}$ soud. Poškozený v postavení žalobce má však jen omezené možnosti $\mathrm{k}$ získání potřebných důkazů. Často je pak ani nebude schopen dostatečně popsat tak, aby soud mohl přistoupit k jejich obstarání postupem dle $\ 129$ odst. 2 OŠ̌. Poškozený totiž mnohdy dokáže určit, o jaké dokumenty se jedná, avšak pouze typově, nedokáže tedy dostatečně popsat konkrétní dokument, který by měl soud obstarat. Vzniká tak jistá nerovnováha v postavení žalobce a žalovaného - i v situaci, kdy je nepochybné, že škoda vznikla, může poškozený ztratit spor právě z důvodu důkazní nouze. Potřebné důkazy prítom mohou existovat, poškozený $\mathrm{v}$ roli žalobce $\mathrm{k}$ nim však nedokáže sobě resp. soudu zajistit př́stup.

Návrh směrnice spatřuje řešení v přijetí dvou nástrojů. Prvním je snazší př́stup $\mathrm{k}$ dokumentům obsaženým ve správním spise soutěžního orgánu, druhým je specifická úprava ediční povinnosti žalovaného. Oběma nástrojům se hodlám věnovat odděleně.

31 S využitím zákonných nástrojů, např̀. ediční povinnosti dle $\int 129$ odst. 2 OSŘ. 


\section{K prístupu do spisu soutěžního orgánu}

Jádrem popsané komplikace se na první pohled zdá být zajišsění př́stupu žalobce, resp. soudu k dokumentům, obsaženým ve spise soutěžního orgánu. Za tímto řešením stojí jasná a prìiatelná úvaha. Soutěžní orgán se věnuje vymáhání soutěžního práva v správněprávní větvi, má silné pravomoci, jejichž účelem je zajištění podkladů pro své rozhodnutí. Ve správním spise by se tak měly nacházet i dokumenty s důkazní hodnotou pro civilní spor o náhradu škody. Jedná se však o vhodné řešení jen zdánlivě. Soutěžní orgán se prítom př́stupu osob mimo okruh účastníků řízení bránî̉ ${ }^{32}$ Důvodem je skutečnost, že informace, obsažené ve správním spise, jsou mnohdy předmětem obchodního tajemství, a to nejen účastníků řízení, prrípadně je prúístup $\mathrm{k}$ nim jinak omezen. Soutěžní orgán se při vyšetřování soutěžních deliktů může obrátit na široce vymezený okruh subjektư, které jsou povinny mu sdělit vyžádané informace a poskytnout podklady ${ }^{33}$. V situaci, kdy by tyto podklady byly dále snadno dostupné, lze důvodně očekávat, že ochota takových subjektů vyžádané informace poskytovat, bude výrazně omezena. Snadný př́istup do spisu by pritom mohl vést i k ohrožení základní pravomoci soutěžních orgánů.

Od príistupu do spisu správního orgánu však nelze bez ohledu na výše uvedené očekávat zlepšení důkazní situace žalobce. Pro správné pochopení nevhodnosti tohoto přistupu si je nezbytné uvědomit zásadní rozdíl mezi správním a civilním procesem v soutěžní věci. Ve správním řízení je př̌edmětem šetření soutěžního orgánu soutěžitel, jeho deliktní chování je následně přičteno konkrétní osobě. Vznik škody, poprípadě její výše je pak pro soutěžní orgán $\mathrm{v}$ řadě př́padů bez významu (nebot' některé protisoutěžní dohody jsou nebezpečné i bez vzniku škody), $v$ jiných prípadech pak stačí, že šetřené protisoutěžní jednání mělo negativní dopad na trh větší než nepatrný. Konkrétní výše či přičitatelnost z pohledu civilního však není předmětem šetření soutěžního orgánu. Oproti tomu v civilním procesu bude předmětem dokazování delikt, vznik škody, kauzální nexus a výše škody. $Z$ prostého porovnání snadno zjistíme, že soutěžní orgán směřuje svou činnost k prvnímu ze zmíněných předmětů, vznik škody a kauzální nexus chápe autonomně a přesná výše škody není předmětem jeho zájmu. Zároveň je správní orgán vázán zásadou enumerativnosti veřejnoprávních pretenzí, není mu tedy dáno zjišt’ovat a dokazovat skutečnosti nad rámec zákonného vymezení jeho činnosti.

Za zmínku stojí taktéž snaha soutěžního orgánu omezit př́stup k některým specifickým dokumentům, typicky původem $z$ leniency žádosti ${ }^{34}$. Již z účelu a funkce leniency však vypovídá, že v ní obsažené dokumenty nebudou nápomocny ke snazšímu dokazování

32 Rozsudek Krajského soudu v Brně ze dne 19. 2. 2015, sp. zn. 62 Af 82/2013 ve věci Sokolovská ubelná.

$33 \rrbracket 21$ e ZOHS.

34 Oznámení Úřadu pro ochranu hospodářské soutěže ze dne 4. Listopadu 2013 o aplikaci $\ 22$ ba odst. 1 zákona o ochraně hospodářské soutěže dostupného na https://www.uohs.cz/cs/legislativa/hospodarska-soutez.html 
v civilním sporu o náhradu škody. Účelem leniency není umožnit snazší vymáhání škody, dokumenty za tímto účelem použitelné tedy neobsahuje $\mathrm{e}^{35}$.

Z výše uvedeného je třeba odvodit závěr, že ve správním spise soutěžního orgánu nelze očekávat dostatečné důkazy pro civilní žalobu na náhradu škody. Rozšírené ediční povinnosti soutěžního orgánu, resp. zakotvení možnosti snazšího př́ístupu regulované ve směrnici, resp. zákoně tedy nepovede k výraznému zlepšení procesního postavení žalobce a neodstraní nerovnováhu, popsanou v úvodu této kapitoly.

\section{K ediční povinnosti žalovaného}

Další oblast, ve které lze spatřovat nerovnováhu mezi žalobcem a žalovaným co do důkazní situace, je úprava ediční povinnosti žalovaného. Ediční povinnosti žalovaného odpovídá situace, kdy žalovaný (popřípadě i jiný subjekt) předloží na výzvu soudu dokumenty, detailně popsané žalobcem. Platí přitom, že popis musí být dostatečně přesný. Obecný či nepresný popis navrženého důkazu není dostačující pro jeho obstarání soudem. Předložení důkazů, označených jinak než zcela konkrétně, tzn. obecněji, je nemožné vymoci. Žalovaný zde může v řadě případů uspět s námitkou neurčitosti vymezení dokumentů $\mathrm{k}$ předložení, čímž bude možné účinně bránit vydání potřebných důkazů. Efektivní fungování soukromoprávních žalob je tak dále omezeno.

Zmiňovaná směrnice předpokládá $v$ tomto případě předložení všech dokumentů, které splní vymezená kritéria s vyšší měrou obecnosti ${ }^{36}$, byt's věcí nesouvisejících, s tím, že jejich vyhodnocení provede soud ${ }^{37}$. Takové řešení mám za nadbytečné, když může vést k omylům. Jen žalobce ví, jaké důkazy považuje za vhodné a právě ty navrhuje, soud by neměl zároveň provádět činnost $\mathrm{v}$ důsledku srovnatelnou s označením důkazů a tyto důkazy hodnotit. Zároveň platí, že v opačném případě, kdy by hodnocení předložených dokumentů prováděl žalobce a z nich vybíral ty, které navrhne provést jako důkaz, hrozí zneužití tohoto postupu k zajištění přístupu k jinak nedostupným informacím se sporem nesouvisejícím.

V současném právním řádu lze nalézt př́hodnější nástroj, směřující ke stejnému cíli, avšak bez zmíněných negativ. Je jím vysvětlovací povinnost, resp. povinnost substanco-

35 NEJEZCHLEB, Kamil. Vzájemný vliv veřejnoprávní ochrany hospodářské soutěže a soukromoprávního vymáhání škody způsobené porušením soutěžního práva - role soft law. COFOLA 2015. Lednice, 17. 4. 2015. Pozn.: Postkonferenční sborník nebyl ke dni odevzdání tohoto článku dostupný. V průběhu recenzního řízení byl sice postkonferenční sborník vydán, avšak předmětný příspěvek v něm není obsažen. Dle sdělení autora byl vybrán pro publikaci v ČPVP, k tomu však k 14. 6. 2016 nedošlo.

36 Čl. 5 směrnice.

37 Čl. 5 odst. 4 směrnice. 
vání, známá z děl prof. Macura či Tichého ${ }^{38}$. Detailní rozbor tohoto procesního institutu není předmětem tohoto článku, dostatečným je stručné shrnutí. Subjekt, povinný v rámci vysvětlovací povinnosti, je soudem vyzván, aby se vyjádřil k jemu předloženým skutečnostem, odpověděl dotazy, případně své odpovědi i důkazně podložil. Nemusí se vždy jednat jen o stranu sporu, k popsanému může být i donucen, jedná se tedy $\mathrm{v}$ procesním smyslu o povinnost, nikoli břemeno. Žalobce zatížený touto povinností by pak byl v rámci této povinnosti povinen poskytnout vysvětlení ke skutečnostem, které žalovaný dokáže. Soudu tak umožní seznat lépe skutkový stav věci. Takový postup by následně mohl sloužit $\mathrm{k}$ doplnění skutečností, nutných k řádnému označení důkazů pro účely aplikace ediční povinnosti. Tento postup nemá žádnou z nevýhod, popsaných výše a dostatečně přitom plní sledovaný účel.

\section{Závěr}

V tomto článku jsem představil základní problematické momenty, na které naráží praxe v řízeních o nárocích na náhradu škody z protisoutěžních deliktů dle právního stavu před implementací směrnice o určitých pravidlech upravujících žaloby o náhradu škody podle vnitrostátního práva $\mathrm{v}$ př́ípadě porušení právních předpisů členských států a Evropské unie o hospodářské soutěži. U všech těchto problematických momentů jsem rozebral východiska, ze kterých pramení, popsal způsob, jakým tyto žaloby komplikují a vedou ke zhoršení postavení žalobce a tím i nižší efektivitě celého systému. Následně jsem se pokusil nastínit řešení, odpovídající současnému právnímu řádu. Naznačil jsem také řešení těchto komplikací, jak je navrhuje zmíněná směrnice. Došel jsem k závěru, že není právního důvodu, aby soukromoprávní vymáhání škody z protisoutěžních deliktů v českém právním řádu nefungovalo a zmíněná směrnice neobsahuje jednoznačné nástroje, které by vedly ke zvýšení atraktivity tohoto druhu řízení pro žalobce.

38 Stručně např. STAVINOHOVÁ, Jaruška Procesní povinnosti účastníků civilního soudního řízení ve světle díla prof. Macura. Dny práva 2008. Brno, 2008. Cit. dne 20. 7. 2015. Dostupné na http://www. law.muni.cz/sborniky/dp08/files/pdf/SBORNIK.pdf.

TICHÝ, L. Pravděpodobnost v hmotném právu a míra důkazů (skica o možné změně paradigmatu v NOZ). Bulletin advokacie. Praha, 2013, č. 12. 